\title{
PRECONDITIONS OF THE FORMATION OF THE CHILDREN'S AND ADOLESCENTS' HYGIENE AS A BRANCH OF MEDICAL SCIENCE AND PRACTICE IN UKRAINE
}

\author{
Stasiuk L.A.

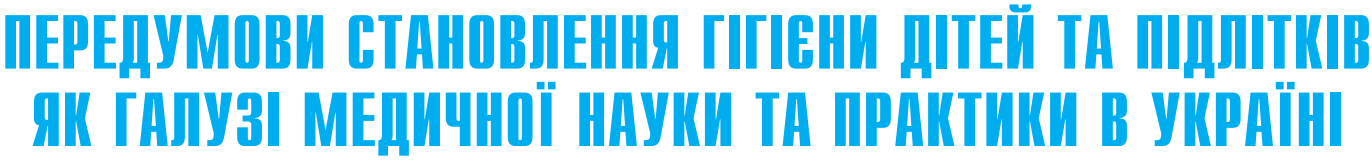

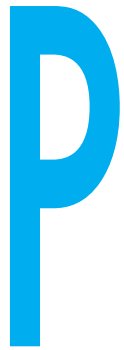

СТАСЮК Л.А

Національний

медичний

університет

ім. О.О. Богомольця

М. Київ

УДК 378.661(477-25)

Ключові слова:

гігієна дитинства,

гігієна дітей

та підлітків,

земська

медицина,

народна

попереджувальна

медицина. озвиток гігієни дитинства в Україні сягає своїми коренями глибини століть, адже на довгому і складному державотворчому шляху успішне вирішення задач збереження здоров'я дитячого населення завжди було запорукою збереження нації. Соціально-політичні перетворення що відбуваються нині і у нашій країні, диктують необхідність обґрунтування шляхів подальшого розвитку профілактичного напрямку медицини дитинства, що неможливо без ретроспективного аналізу формування підґрунтя гігієни дітей та підлітків як галузі медичної науки і практики.

Мета роботи - висвітлення передумов становлення гігієни дітей та підлітків як галузі медичної науки та практики в Україні. Для досягнення мети потрібно було вирішити такі завдання:

口 проаналізувати витоки профілактичного напрямку медицини дитинства як компонента громадської думки;

вивчити особливості розвитку шкільної гігієни в Україні як передумови становлення гігієни дітей та підлітків;

口 визначити роль земської медицини у формуванні науково-практичних основ гігієни дітей та підлітків.

Методи дослідження: бібліографічний, аналітичний, описовий.
Український народ отримав у спадок від носіїв Трипільської культури та Київської Русі не лише територію і генофонд, але й потужний пласт етнокультурних надбань, у тому числі медико-оздоровчих: 3 покоління в покоління передавалися звичаї та навички народного побуту, вірування та уподобання, що мали на меті збереження здоров'я дитини. Створені протягом століть морально-етичні норми (повага і любов до праці, ствердження ідеалів добра, гуманних взаємостосунків, несприйняття шкідливих звичок тощо) передавалися дітям за допомогою народної творчості (казки, думи, пісні) і наочно власним прикладом - у дитини виховувалося бажання бути сильною, мужньою, працелюбною, здоровою.

Історія українського народу - це історія війн, набігів та оборони. За таких суворих обставин вижити могла лише загартована, фізично міцна людина. Проте не лише служба у війську, але й повсякденна праця різних соціальних верств населення вимагала оволодіння практичними навичками, в основі яких були такі фізичні якості, як сила, гнучкість, швидкість та витривалість. Таким чином, витоки гігієни дітей та підлітків сягають глибокого минулого нашого народу, ще дохристиянської епохи.
ПРЕДПОСЫЛКИ СТАНОВЛЕНИЯ ГИГИЕНЫ ДЕТЕЙ И ПОДРОСТКОВ КАК ОТРАСЛИ МЕДИЦИНСКОЙ НАУКИ И ПРАКТИКИ В УКРАИНЕ Стасюк Л.А

Национальный медицинский университет им. А.А. Богомольца

Цель работы: исследовать предпосылки становления гигиены детей и подростков как отрасли медицинской науки и практики в Украине. Материалы и методы: архивные данные, библиографический, аналитический, описательный методы.

Результаты. В статье приведен ретроспективный анализ исторических предпосылок возникновения гигиены детей и подростков как отрасли медицинской науки и практики.

Представлены основные этапы развития гигиены детства, особенности формирования ее фундамента в Украине. Определена роль земской медицины в становлении научно-практических основ гигиены детей и подростков.

Выводы. Гигиена детей и подростков, как и каждая наука, развивалась параллельно с развитием общества, согласно его социальным потребностям и запросам, как социальный феномен - адекватно морально-этическим нормам эпохи. Развитие школьной гигиены в Украине имеет свои национальные корни и традиции, которые требуют дальнейшего изучения. Каждый шаг по демократизации общества дает толчок к инициации и внедрению передовых форм и направлений медицины: благодаря деятельности земской медицины санитарно-профилактическое направление не только становится ее неотъемлемой составной частью, но и развивается как ведущее. В это время создаются социальные институты, которые на государственном уровне обобщают опыт работы врачей, внедряют профилактические мероприятия и контролируют их реализацию. Развитие санитарно-профилактического направления, в частности гигиены детства, в деятельности земской медицины создало необходимое теоретическое и практическое основание для выделения гигиены детей и подростков в самостоятельную отрасль медицинской науки и практики.

Ключевые слова: гигиена детства, гигиена детей и подростков, земская медицина, народная предупредительная медицина.

( Кудиевский Я.В., Кальниш В.В. СТАТТЯ, 2016. 
PRE-CONDITIONS OF BECOMING OF HYGIENE OF CHILDREN AND TEENAGERS AS A BRANCH OF MEDICAL SCIENCE AND PRACTICE IN UKRAINE Stasiuk $L$.

National O.O. Bogomolets Medical University Objective: to investigate preconditions of formation of hygiene of children and adolescents as a brunch of medical science and practice in Ukraine. Materials and methods: archival data, bibliographic, analytic, and descriptive methods. Data. The retrospective analysis of historical preconditions of hygiene of children and adolescents origin as a branch of medical science and practice is conducted. The basic stages of hygiene of childhood development, features of forming of her foundation in Ukraine are presented. The role of zemskaya medicine in becoming of research and practice bases of hygiene of children and adolescents is determined. Findings. Hygiene of children and teenagers, like every science, has developed in parallel with the development of society, according to his social needs and demands and, as a social phenomenon adequately with the ethical norms of the era. The development of school hygiene in Ukraine has its own national roots and traditions that require further study. Each step in the democratization of society gives rise to the initiation and implementation of advanced forms of medicine: due to activity of Zemskaya medicine the preventive direction not only becoming an integral part of it, but also develops as a leading. Social institutions at the state level were created at that time; they summarized the experience of doctors, introduced preventive measures and controlled their implementation. Development of the preventive direction in medicine due to activity of zemskaya medicine has created the necessary theoretical and practical basis for the allocation of hygiene of children and adolescents in an independent branch of medical science and practice.

Keywords: hygiene of childhood, hygiene of children and adolescents, zemskaya medicine, preventive folk medicine.
3 появою на Русі шкіл (кінець X століття) здобутки народної попереджувальної медицини стали використовуватися та прищеплюватися дітям у цих навчальних закладах, тобто гігієна дитинства піднялася на новий щабель свого розвитку і почала розвиватися паралельно з розвитком шкільної освіти. Після прийняття християнства у Київській Русі створилася цілісна система освітянських закладів різних типів: це й елітні школи при Десятинній церкві та при Софії Київській, це й нижчі школи і школи при монастирях [1]. Вже за часів Київської Русі з'явилися перші друковані праці, де викладено найпростіші правила профілактики шкідливих звичок у дітей, які не втратили актуальності й нині. Так, у вітчизняній пам'ятці з гігієни виховання XI сторіччя «Повчання Володимира Мономаха дітям» йдеться: «...бережися і пияцтва, і блуду, бо в сьому душа погибає і тіло...», а у «Медичному трактаті» онука князя Володимира Мономаха Євпраксія йдеться про необхідність щоденного умивання та обтирання холодною водою, дотримання чистоти одягу, активного відпочинку на свіжому повітрі незалежно від погоди, вивчення військового ремесла та іноземних мов $з$ дитинства.

Слід зазначити, що громадський побут кожного етносу - не застигле явище, а динамічна система, в якій відбувається постійна взаємодія старих та нових форм: традиції постійно трансформуються відповідно до потреб часу, а інновації можуть перетворюватися на традиції, якщо громадська думка оцінила їхню дієвість. Школа, що пара- лельно з наданням основ знань прищеплювала дітям навички здорового способу життя, провадила санітарну просвіту серед дітей та юнацтва, протягом усього періоду розвитку нації розглядалася громадською думкою як необхідний компонент побуту українців.

Особливості географічного розташування (центр Європи) та історичного розвитку зумовили у XIV-XVI століттях якісне розмаїття закладів освіти на теренах України. У той період функціонували як світські (міські та магістратські), так і духовні школи при монастирях та релігійних общинах (католицькі, єврейські, єзуїтські, уніатські та, звичайно, православні), розширювалася мережа приватних шкіл [1]. Але провідну роль у становленні та розвитку системи освіти і вихованні паростків демократії в Україні відігравали братські школи, що створювалися 3 ініціативи національнорелігійних об'єднань («братств»). Так, до школи Луцького братства приймали дітей усіх станів та верств, від маєтних шляхтичів та міщан до бідняків, які просили милостиню на вулиці. Причому вихователям суворо наказувалося не робити між ними ніякої різниці, окрім як залежно від успіхів у навчанні. Усі школярі по черзі повинні були топити печі, прибирати приміщення тощо. У козацьку епоху розвитку українського суспільства провідними закладами шкільної освіти стали козацькі (на Гетьманщині) та січові (на Запорозькій Січі) школи. У кожному селі діяли так звані парафіяльні школи, де протягом трьох років діти вчилися писати, читати, рахувати та співати, вивчали Закон Божий. Крім того, діяли професійні школи. Таким чином, на початку XVIII століття кожна дитина мала змогу ходити до школи, і Україна була країною практично цілковитої грамотності. Доречно згадати, що перша шкільна будівля в Україні була збудована у 1635 році за ініціативи засновника Київської колегії Петра Могили. Паралельно з розвитком системи освітянських закладів відбувався процес систематизації накопичених знань з особистої гігієни та профілактики захворювань у дітей, що наочно можна прослідкувати, читаючи такі стародруки, як «Домострой» (XV-XVI ст.), «Азбуковники» (XVII ст.), «Громадянство звичаїв дитячих» Епіфанія Славінецького (XVII ст.), «Юності чесне зерцало» (XVIII століття), «Регламент, або статут духовних академій» Феофана Прокоповича (1721). Зокрема, в останній праці подано перші гігієнічні рекомендації щодо організації навчальних закладів: «Школи варто розміщати не у місті, але осторонь, де нема народного шуму... За учнями необхідно слідкувати, щоб у визначені години всяк робив, що повинен... На всяк день дві години визначити на гуляння... по обіді і по вечері з іграми чесними та тілорухомими...» [2].

На жаль, протягом XVII-XIX століть в Україні (вже Малоросії) накопичувався і негативний досвід організації навчання та виховання: у навчальних закладах панувала казенна дисципліна, схоластичні методи викладання, фізичні покарання. Проте крізь циркулярний пласт імперських вимог та свавілля адміністрації пробивалися про- 
гресивні ідеї та думки. Наприклад, ще у 1750 році молодий викладач поетики Переяславського колегіуму і майбутній філософ Г.С. Сковорода рішуче відмовився від застарілих підручників та методів виховання. Його теза «учитель и врач ... только служитель природы, единственной истинной и врачебницы, и учительницы» та ідея «природо відповідного виховання» актуальні й нині [3].

Яскраву сторінку у розвиток шкільної гігієни в Україні XIX століття вписали два видатні лікарі того часу - I.C. Орлай (17701829) та М.І. Пирогов (18101881). Вважаючи, що прогресивний розвиток суспільства можливий лише за умови реорганізації народної освіти, та керуючись ідеєю служіння народу, вони кардинально змінили свою професійну діяльність. Вчений секретар медико-хірургічної академії, гоф-хірург ії IMператорської Величності (особистий лікар Олександра I), учений-енциклопедист І.С. Орлай, маючи за плечима ґрунтовну освіту кількох західних університетів, захист дисертацій на звання доктора медицини і хірургії, доктора філософії, магістра словесних наук, очолює послідовно Гімназію вищих наук князя Безбородька у м. Ніжині (1821-1826) та Рішельєвський ліцей в Одесі (1926-1929). На цих посадах він проявив себе талановитим організатором педагогічної справи. Дотримуючись передових на той час педагогічних поглядів Песталоцці, І.С. Орлай впроваджував у життя ідеї демократизації навчально-виховного процесу. Медикопедагогічне забезпечення, що започаткував І.С. Орлай у Гімназії вищих наук, стало взірцем для інших навчальних закладів в Україні, зокрема пансіонів, а наявність при Гімназії лікарні дала змогу хворобливому Микоші Яновському навчатися, і після дев'ятирічної огранки його таланту у цьому навчальному закладі світ отримав письменника М.В. Гоголя [2].

Непересічна постать М.І. Пирогова у галузі народної освіти $€$ не менш значущою, ніж у медицині. Видатний хірург того часу, член-кореспондент Академії наук, академік Медико-хірургічної академії, лауреат двох повних Демидівських премій Академії наук, почесний член Московського, Харківського та Київського університетів, про- фесор кафедри госпітальної хірургії, патологічної та хірургічної анатомії Медико-хірургічної академії, засновник військовопольової хірургії М.І. Пирогов 3 вересня 1856 року працює попечителем Одеського навчального округу, а з вересня 1858 року - Київського навчального округу, на практиці втілюючи свої ідеї з гуманізації освіти.

M.І. Пирогов вважав педагогіку мистецтвом, навчальний процес вимагав організовувати з використанням наочних засобів відповідно віку дитини, нещадно боровся $з$ низьким рівнем викладання, свавіллям адміністрації, фізичними покараннями та іншими негативними явищами, що були характерні для освітянських закладів того часу, вказував на необхідність мати лікаря у кожному навчально-виховному закладі [4]. Ще 1857 року він обґрунтував необхідність створення Новоросійського університету в Одесі 3 трьома факультетами (фізико-математичним, історико-філологічним та медичним), був одним із засновників медичного факультету Університету св. Володимира у м. Києві та доклав значних зусиль до створення окремої кафедри з питань профілактичної медицини.

Величезний пласт напрацювань, що залишили нащадкам ці непересічні особистості, ще чекає своїх дослідників медиків і педагогів. Вислів І.С. Орлая «Доброе воспитание юношества есть первая основа благосостояния государства», як і геніальна теза М.І. Пирогова «Майбутнє належить медицині запобіжній» в умовах реалій сьогодення залишаються надзвичайно актуальними.

Цінний вклад у розвиток шкільної гігієни зробив наш співвітчизник, відомий педагог XIX століття К.Д. Ушинський (18241871), який вважав, що основою педагогіки має бути медикопсихологічне підґрунтя - анатомія, фізіологія та психологія [5].

Суттєвий внесок у розвиток та формування науково-практичних основ гігієни дітей та підлітків зроблено у період існування земської медицини, організація якої була суто суспільною справою. Від зародження («Положення про губернські та повітові земські установи» від 1 січня 1864 року) та увесь період свого функціонування (до 1917 р.) земська медицина не лише вирішувала в Україні питання лікарської допомоги населен- ню, але й здійснювала профілактичні заходи серед широких мас населення. Після відміни кріпацтва (1861) на півдні України інтенсивніше, ніж в інших регіонах, розвивалися капіталістичні відносини не лише у промисловості, але й у сільському господарстві. Останне викликало інтенсивну міграцію населення. Саме з південного кордону поширювалися епідемії малярії, тифу, туберкульозу, дифтерії та інших інфекційних хвороб, обумовлюючи високу дитячу смертність. Тому у 1865-1872 роках в українських губерніях, передусім у південних, розгортається медична діяльність повітових земств, які зосереджують свою роботу, зокрема, на протидії епідеміям та оздоровленні сезонних робітників, серед яких (особливо на бурякових плантаціях) переважали жінки та діти [6]. Земські лікарі, входячи до складу опікунських рад, вирішували питання поліпшення санітарного стану вже існуючих земських та церковно-приходських шкіл, організації та будівництва нових земських шкіл, ясел і будинків соціального призначення (притулків); проводили медичні огляди школярів зі статистичним узагальненням отриманих даних, протиепідемічні заходи.

Недостатня ефективність санітарно-гігієнічних заходів, які проводили лікувальні заклади у 60-70 роках XIX століття, обумовила появу думки про доцільність поглиблення спеціальних гігієнічних знань у лікарів. 1871 року на медичному факультеті Київського університету св. Володимира (вперше у Російській імперії) та у 1873 році на медичному факультеті Харківського університету були створені кафедри гігієни, що стали центрами наукових досліджень у галузі шкільної гігієни. Однак передумови формування наукових основ гігієни дитинства в Україні закладалися на початку XIX століття професорами інших галузей медичної науки. Зокрема, ще у 1812 році професор акушерства Харківського університету І. Каменський зробив доповідь на тему: «Про фізичне виховання дітей і про його вплив на розумовий та психічний розвиток» [7].

Слід зазначити, що наукові дослідження гігієнічних кафедр базувалися на останніх на той час досягненнях вітчизняної і зарубіжної медицини. Завідувачі 
кафедр та провідні викладачі стажувалися у наукових центрах Франції, Німеччини, США. Зокрема, приват-доцент Субботін В.А., який очолив кафедру гігієни, медичної поліції, медичної географії і статистики Київського університету св. Володимира, під час дворічного стажування за кордоном ґрунтовно ознайомився 3 досягненнями передових гігієнічних центрів європейської медичної школи [8]. Кафедру гігієни Новоросійського університету у м. Одесі (1893) i, відповідно, гігієнічну наукову школу створив професор В.Г. Хлопін, який мав на той час не лише 5-річний досвід роботи у Московському університеті під керівництвом видатного вченого-гігієніста Ф.Ф. Ерісмана, але й 8-річний досвід науково-педагогічної діяльності у Дерптському університеті. Слід згадати, що разом з професором В.Г. Хлопіним із Дерпту до Одеси переїхав молодий вчений К.Е. Добровольський (1867-1947), щоб у майбутньому очолити кафедру гігієни у Київському медичному інституті [9]. За керівництва професора Г.В. Хлопіна було проведено масштабні дослідження захворюваності дітей шкільного віку (обстежено 116458 учнів шкіл різного типу) з ґрунтовним аналізом причин та висвітленням проблем формування здоров'я у навчальних закладах того часу. Таким чином, було закладено науково-експериментальний базис нового напрямку розвитку гігієни - гігієни дитинства. Результати цих досліджень були відзначені педагогічною Академією Ліги освіти Франції, яка 1910 року обрала вченого професором та почесним членом її генеральної ради як фахівця 3 шкільної гігієни. Перу Г.В. Хлопіна належить 7 наукових публікацій 3 гігієни дитинства. Беззаперечною заслугою вченого також стала організація шкільно-гігієнічного відділу на Міжнародній виставці у Дрездені, який привернув увагу міжнародної спільноти до нової галузі медичної науки та практики [7].

Професор А.І. Якобій (18371907), який очолював кафедру гігієни Харківського університету (1872-1885), започаткував новий напрям викладання гігієни. Він викладав її не як суто особисту, а як суспільну експериментальну науку. 1985 року стараннями його учнів побачив світ посібник з гігієни «Курс суспільної гігієни» за редакцією професора A.І. Якобія. В окре- мому розділі цього посібника під назвою «Школа» висвітлено актуальні питання шкільної гігієни: перераховано захворювання дітей, що зумовлені незадовільним гігієнічним станом навчальних закладів, обґрунтовано заходи їх профілактики [10].

Проте кожна нація як організована структурна одиниця ноосфери з метою самозбереження та подальшого свого розвитку повинна не лише розробляти форми й засоби зміцнення здоров'я дитячої популяції, але й створювати соціальні інститути, що на державному рівні контролювали б процес реалізації профілактичних заходів, їхню ефективність. Саме тому земства постійно шукали шляхи розвитку та вдосконалення медичної мережі, у тому числі санітарногігієнічного спрямування. Так, у 1874 році на Херсонщині було створено першу санітарну організацію - санітарно-статистичне бюро як центр координації медичної допомоги населенню [11]. Таким чином, було створено умови для проведення санітарно-статистичних досліджень та наукового аналізу залежності здоров'я дітей та підлітків від умов їхнього життя, навчання та виховання.

Наступним кроком у наданні земській медицині санітарнопротиепідемічного напрямку розвитку як провідного було затвердження посади губернського санітарного лікаря при Херсонському губернському повіті (1875) та посад санітарних лікарів у кожному повіті (1885) Херсонської губернії. Позитивний досвід організації санітарно-гігієнічної роботи земства поступово поширюється на усі губернії України. Слід зазначити, що розвиток санітарно-профілактичного напрямку діяльності земської медицини сприяв вихованню санітарних лікарів як громадських діячів та науковців. Узагальнюючи досвід своєї роботи, вони мали можливість знайомити широку громадськість 3 гігієнічними проблемами та пропонувати шляхи розв'язання їх на сторінках журналів-бюлетенів «Врачебно-санитарная хроника», що видавались у 6 з 8 українських губерній [12].

Важливу роль у становленні та розвитку земської медицини відігравали і губернські з'їзди лікарів та з'їзди «Товариства лікарів у пам'ять Пирогова», що після свого створення стало основним координатором розвитку медицини та шкільної гігієни. Так, у програмі діяльності земських санітарних лікарів, прийнятій на XII Пироговському з'їзді (1913), визначено як обов'язковий «шкільно-санітарний нагляд разом з дільничним лікарем і вчителем, оскільки фізичне виховання школярів і проведення основ гігієни через школу $€$ одним 3 наріжних каменів оздоровлення населення та виховання у нього культурних навичок й гігієнічних потреб» [13].

Слід зазначити, що одним 3 основних завдань земської медицини була санітарно-просвітницька робота серед населення. Значну роль у поширенні гігієнічних знань серед школярів відіграли і комісії при Пироговському товаристві лікарів. Зокрема, 1896 року ця організація розробила типові програми викладання гігієни у різних навчальних закладах. Один 3 організаторів земської медицини в Україні С.М. Ігумнов (18641942) на сторінках "Журнала Общества русских врачей в память Н.И. Пирогова» пропагував оздоровчі заходи, спрямовані на зниження показників дитячої смертності, зокрема, відстоював необхідність організації дитячих ясел та ясел-притулків. На думку С.М. Ігумнова, такі заклади виконували б не лише оздоровчу функцію, але й здійснювали б загальнокультурний вплив на сім'ю [14].

Цікавою формою та позитивним кроком на шляху залучення широких верств населення до проведення оздоровчих закладів було впровадження постійних санітарних кураторств. Одним з питань, що перебували під патронатом цих громадських організацій, була, наприклад, організація у школах гарячих сніданків для учнів [15].

Таким чином, у період діяльності земської медицини санітарно-профілактичний напрямок їі діяльності розвивався як провідний і став її невід'ємною складовою. Останнє зумовило не лише збереження етнокультурних надбань народу за попередні століття, але й накопичення великого пласту науково-практичних досягнень у галузі профілактики захворювань, зокрема дитячих. За цей час було остаточно створено підґрунтя для виокремлення гігієни дитинства у самостійну галузь медичної науки та практики, засновано наукові школи, що отримали міжнародне визнання. 


\section{Висновки}

1. Гігієна дітей і підлітків, як і кожна наука, розвивалася паралельно з розвитком суспільства, відповідно до його соціальних потреб і запитів, і як соціальний феномен, адекватно моральноетичним нормам епохи.

2. Розвиток шкільної гігієни в Україні має свої національні корені і традиції, що потребують подальшого вивчення.

3. Кожний крок з демократизації суспільства дає поштовх до ініціації та впровадження передових форм і напрямків медицини: за діяльності земської медицини (1864-1917) санітарно-профілактичний напрямок не лише стає невід'ємною її складовою, але й розвивається як провідний. У цей час були створені соціальні інститути, що на державному рівні узагальнюють досвід роботи лікарів, впроваджують профілактичні заходи та контролюють процес їх реалізації.

4. Розвиток санітарно-профілактичного напрямку, зокрема гігієни дитинства, у діяльності земської медицини створив необхідне теоретичне та практичне підґрунтя для виокремлення гігієни дітей та підлітків у самостійну галузь медичної науки та практики.

ЛІТЕРАТУРА

1. Полька Н.С. Гігієна дітей і підлітків в Україні: історія і сьогодення / Н.С. Полька, Н.Я. Яцковська, Г.М. Єременко // Медико-екологічні та соціально-гігієнічні проблеми збереження здоров'я дітей в Україні : зб. тез доп. науково-практ. конФ. - Київ, 2009. - С. 11-18.

2. Історичні аспекти формування здорового способу життя дітей та підлітків в Україні / Л. Стасюк, М. Баранова, Р. Бевз, Л. Гармаш // Гуманітарний вісник державного вищого навчального закладу «Переяслав-Хмельницький державний педагогічний університет імені Григорія Сковороди». - 2013. - Вип. 30. - С. 571-576.

3. Сковорода Григорій : дослідження, розвідки, матеріали : збірник наукових праць / упоряд. В.М. Нічик,

Я.М. Стратій. - К. : Наукова думка, 1992. - 382 с.

4. Пирогов Н.И. Избранные педагогические сочинения / сост. А.Н. Алексюк, Г.Г. Савенок. - М. : Педагогика, 1985. -496 c.

5. Ушинський К.Д. Вибрані педагогічні твори: у 2-х т. - Т. 1. Теоретичні проблеми педагогі- ки / К.Д. Ушинський ; за ред. О.І. Піскунова. - К. : Рад. школа, 1983. - 488 с.

6. Уваров М.С. Программа исследования пришлых рабочих и надзора за ними /

М.С. Уваров // Сб. Херсонского земства. - Херсон, 1889. № 3. - C.16-27.

7. Коцур Н.І. Становлення i розвиток гігієнічної науки в Україні: шлях крізь епохи і соціальні потрясіння (друга половина XIX - 20-ті роки XX століття): монографія / Н.I. Коцур. Корсунь-Шевченківський, 2011. - С. 101-102, 446, 503.

8. Бардов В.Г. Кафедра гігієни та екології Національного медичного університету імені О.О. Богомольця (етапи розвитку, науково-педагогічна діяльність) / В.Г. Бардов,

С.Т. Омельчук,

А.М. Гринзовський // Довкілля та здоров'я. - 2015. - № 5 (76). - С. 32-38.

9. Особиста справа К.Е. Добровольського // Архів НМУ імені О.О. Богомольця.

10. Якобий А.И. Курс общественной гигиены (написано от руки, размножено литографическим способом) / А.И. Якобий. -1885.

11. Бессалов В.С. 100-летие санитарно-эпидемиологической службы / В.С. Бессалов, А.А. Коваль // Итоги и перспективы исследований по истории медицины / ред. Ю.П. Лисицин, Г.Р. Крючко]. - Ташкент :

Медицина, 1980. - 762 с.

12. Володимир Підгаєцький: Повернення із забуття. 18891937 / Ю.І. Кундієв,

О.П. Яворовський, І.М. Трахтенберг, І.М. Сахарчук. - Житомир : Полісся, 2008. - 324 с.

13. О направлении общественной санитарной деятельности и программе работ земских санитарных врачей // XII

Пироговский съезд. - СПб,

1913. - С. 33.

14. Игумнов С.Н. О задачах земской санитарии / С.Н. Игумнов // Журн. Общества русских врачей в память

Н.И. Пирогова. - 1903. - № 3. - С. 17-18.

15. Ігумнов С.М. Нарис розвитку земської медицини на Україні / С.М. Ігумнов // Матеріали до історії розвитку охорони здоров'я на Україні / за ред. К.Ф. Дупленко. - К., 1957. $-387 \mathrm{c}$.

REFERENCES

1. Polka N.S., Yatskovska N.Ya., Yeremenko G.M. Hihiiena ditei i pidlitkiv v Ukraini: istoriia i sohodennia [Hygiene of Children and Adolescents in Ukraine : The History and the Present]. In : Medyko-ekolohichni ta socialno-hihiienichni problemy zberezhennia zdorovia ditei v Ukraini : Zbirka tez dopovidei naukovo-praktychnoi konferentsii [Medico-Ecological and SocialHygienic Problems of the Children's Health Preservation in Ukraine : Abstracts of the Scientific-Practical Conference]. Kyiv; 2009 : 11-18 (in Ukrainian).

2. Stasiuk L., Baranova M.,

Bevz R., Harmash L. Istorychni aspekty formuvannia zdorovoho sposobu zhyttia ditei ta pidlitkiv v Ukraini [Historical Aspects of the Healthy Life Style Formation of the Children and Adolescents in Ukraine]. In : Humanitarnyi visnyk derzhavnoho vyshchoho navchalnoho zakladu «PereiaslavKhmelnytskyi derzhavnyi pedahohichnyi universytet imeni Hryhoriia Skovorody»

[Humanitarian Bulletin of the State Higher Educational Institution "PereiaslavKhmelnytskyi State Hryhorii Skovoroda Pedagogical University"]. PereiaslavKhmelnytskyi (Ukraine) ; 2013 ; 30 : 571-576 (in Ukrainian).

3. Nichyk V.M., Stratii Ya.M. (eds). Skovoroda Hryhorii : doslidzhennia, rozvidky, materialy : zbirnyk naukovykh prats [Hryhorii Skovoroda : Research, Survey, Materials : Collection of the Scientific Works]. Kyiv :

Naukova dumka ; 1992 : 382 p. (in Ukrainian).

4. Aleksiuk A.N., Savenok G.G. (eds). Pirogov N.I. Izbrannye pedagogicheskie sochineniia [Selected Pedagogical Compositions]. Moscow : Pedagogika ; 1985 : 496 p. (in Russian).

5. Ushynskyi K.D. Vybrani pedahohichni tvory. T. 1. Teoretychni problemy pedahohiky [Selected Pedagogical Compositions. Vol. 1. Theoretical Problems of Pedagogics]. Kyiv : Radianska shkola ; 1983 : 488 p. (in Ukrainian).

6. Uvarov M.S. Programma issledovaniia prishlykh rabochikh i nadzora za nimi [Programme for the Examination of

ComingWorkers and Their Supervision]. In : Sbornik Khersonskogo zemstva [Digest of the Kherson Zemstvo]. Kherson ; 1889 ; 3 : 16-27 (in Russian).

7. Kotsur N.I. Stanovlennia i rozvytok hihiienichnoi nauky v Ukraini: shliakh kriz epokhy i sotsialni potriasinnia (druha polovy- 
na XIX - 20-ti rr. XX stolittia): monohrafiia монографія [Formation and Development of the Hygienic Science in Ukraine: The Way Through the Epochs and Social Shocks]. Korsun-

Shevchenkivskyi (Ukraine) ; 2011 : 101-102, 446, 503 (in

Ukrainian).

8. Bardov V.G., Omelchuk S.T., Hrynzovskyi A.M. Dovkillia ta zdorovia. 2015 ; 5 (76) : 32-38 (in Ukrainian).

9. Osobysta sprava K.E. Dobrovolskoho [Personal Affair of K.Ye. Dobrovolskyi]. In : Arkhiv

Natsionalnoho medychnoho universytetu imeni O.O. Bohomoltsia [Archives of the National O.O. Bohomolets Medical University] (in Ukrainian).

10. Yakobii A.I. Kurs obshchestvennoi gigieny (napisano ot ruki, razmnozheno litograficheskim sposobom) [Course of Public Hygiene (Copied by Hand, Propagated Lithographically)]. Kharkov ; 1885 (in Russian).

11. Bessalov V.S., Koval A.A. 100-letie sanitarno-epidemiologicheskoi sluzhby [Centenary of the Sanitary-Epidemiological Service]. In : Itogi i perspektivy issledovanii po istorii meditsiny [Results and Prospects of the Research on History of Medicine]. Tashkent : Meditsina ;1980 : 762 p. (in Russian). 12. Kundiiev Yu.I., Yavorovskyi O.P., Trakhtenberh I.M. Sakharchuk I.M. Volodymyr Pidhaietskyi: Povernennia iz zabuttia.1889-1937 [Volodymyr Pidhaietskyi: Return from Oblivion]. Zhytomyr : Polissia ; 2008 : 324 p. (in Ukrainian).

13. O napravlenii obshchestvennoi sanitarnoi deiatelnosti i programme rabot zemskikh sanitarnykh vrachei [About the Direction of the Public Sanitary Activity and Program of the Works of the Zemstvo Sanitary Doctors]. In : Dvenadtsatyi Pirogovskii sezd [The Twelfth Pirogov Congress]. Sankt-Peterburg ; 1913 : 33-33 (in Russian).

14. Igumnov S.N. Zhurnal Obshchestva russkikh vrachei v pamiat N.I. Pirogova. 1903 ; 3 ; 17-18 (in Russian).

15. Ihumnov S.M. Narys rozvytku zemskoi medytsyny na Ukraini. Materialy do istorii rozvytku okhorony zdorovia na Ukraini. [Essay on the

Development of the Zemstvo Medicine in Ukraine. Materials on the History of the Development of Health Protection in Ukraine]. Kyiv ; 1957 : 387 p. (in Ukrainian).

Надійшла до редакції 21.03.2016

\section{DETERMINATION OF THE PROFESSIONAL RISK LEVEL OF THE OCCURANCE OF DUST ETIOLOGY DISEASES IN MINERS Cheberiachko S.I., Yavorska O.O., Cheberiachko Yu.I. ВИЗНАЧЕННЯ РІВНЯ ПРОФЕСИЙНОГО РИЗИКУ ВИНИКНЕННЯ У ГІРНИКІВ ЗАХВОРНВВАНЬ ПИЛОвої етІОЛОГї}

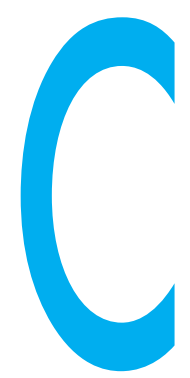

ЧЕБЕРЯЧКО C.I. ЯВОРСЬКА 0.0., ЧЕБЕРЯЧКО Ю.І. Державний ВНЗ «Національний гірничий університет», м. Дніпро

удК. $665.66: 614.89$ итуація стосовно професійних захворювань в Україні є досить складною. В умовах, що не відповідають санітарним нормам, працюють близько 70\% шахтарів. Найшкідливіші виробничі фактори на робочих місцях гірників - це вугільнопородний пил, шум, вібрація, несприятливий мікроклімат. Більше половини профзахворювань мають пилову етіологію, тобто являють собою пневмоконіози різного виду і ступеня тяжкості. Крім того, збільшилася кількість випадків професійного раку легенів через довгостроковий вплив пилу на робочих місцях. Так, за даними Міжнародної організації праці, зареєстрований професійний рак становить близько $16 \%$ усіх випадків злоякісних новоутворень. Це значно збільшує соціальну напруженість у гірничих регіонах: зростають інвалідність, смертність, скорочується загальна тривалість життя шахтарів.

Проблему можна вирішити, якщо використовувати сучасні технічні засоби колективного захисту (вентиляцію; місцеві відсмоктувачі, вбудовані у комбайн;

ОПРЕДЕЛЕНИЕ УРОВНЯ ПРОФЕССИОНАЛЬНОГО РИСКА

ВОЗНИКНОВЕНИЯ У ГОРНЯКОВ ЗАБОЛЕВАНИЙ

ПЫЛЕВОЙ ЭТИОЛОГИИ

Чеберячко С.И., Яворская О.О., Чеберячко Ю.И.

ГВУЗ «Национальный горный университет», Г. Днепр

Основная проблема. Управление профессиональными рисками. Оценка их влияния на профессиональные заболевания и поиск путей уменьшения профессиональных заболеваний пылевой этиологии у работников горных предприятий.

Цель работы. Определение уровня профессионального риска возникновения заболеваний органов дыхания пылевой этиологии у горняков при использовании респираторов.

Материалы и методы. Для расчета уровня риска была использована методика, предложенная проф. Новиковым С.М. На ее основе получены результаты, подтверждающие, что воздействие пыли усиливается при значительном превышении ПДК и с увеличением времени пребывания работников в зоне воздействия пылевого фактора.

Результаты. Установлено, что противопылевые респираторы уменьшают степень риска не более чем на 50\%, что не позволяет обеспечить достаточный уровень защиты горняков. При этом превышение в подмасочном пространстве концентрации пыли в респираторе РПА при запыленности воздуха в горных выработках

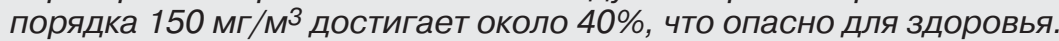
Выводы. За счет правильно подобранных качественных противопылевых респираторов можно снизить риск возникновения заболеваний пылевой этиологии, но не до безопасного уровня. Для этого нужно не только совершенствовать конструкцию респиратора, но и обеспечить мотивацию по их использованию горняками.

() Чеберячко С.І., Яворська О.О., Чеберячко Ю.І. СТАТTЯ, 2016. 